Ankara Üniversitesi

SBF Dergisi,

Cilt 67, No. 2, 2012, s. 95-125

\title{
KAMU ÖZEL ORTAKLLĞ MODELININ MALI DEĞERLENDIRMESi
}

\section{Yrd. Doç. Dr. Yiğit Karahanoğulları}

Ankara Üniversitesi

Siyasal Bilgiler Fakültesi

\section{Özet}

Bu yazıda, 1990'lardan beri Birleşik Krallık'ta uygulanmakta olan, geleneksel kamu yatırım/hizmet üretim modelinden daha verimli olduğu iddiası ile yeni bir model olarak tüm dünyada hızla yaygınlık kazanmaya başlayan ve ülkemizde entegre sağlık hastaneleri için kamunun ihale süreçlerini 2011 yılında başlattığı Kamu Özel Ortaklığı (KÖO) modelinin mali bir değerlendirilmesi sunulmaya çalışılmaktadır. Ortaklık modelinin temel özelliklerinin neler olduğu, çeşitli uygulamalardan hareketle modelden beklenilen amaçlara ulaşılıp ulaşılamadığı, içinde bulunulan kriz konjonktüründe KÖO modelinin "hâlâ" ne derece cazip bir model olduğu gibi sorular makalenin konusunu oluşturmaktadır. Modelin dünyadaki en geniş çaplı ilk uygulamalarını gerçekleştirmiş ve dolayısıyla uzun erimli ilk sonuçlarını da almış olan, pek çok bağımsız kurumun ilgili projelere ve sonuçlarına ilişkin detaylı incelemeler yaptığı Birleşik Krallık deneyimi makalenin temel referansi olacaktır.

Anahtar Sözcükler: Kamu özel ortaklığı, kamu yatırımları, kamu maliyesi, kamu garantileri, bilanço dışılık

\section{A Fiscal Evaluation of the Public-Private Partnership Model}

\section{Abstract}

In this article, Public-Private Partnership model which has been applied in the UK since 1990s and which has spread quickly to other countries with the claim that it is more efficient than the classical public investment model, and by which public authorities started the tendering process for entegrated health facilities in Turkey in 2011, is analyzed with a fiscal perspective. The main characteristics of the partnership model and questions such as 'whether it has been revealed the expected results' or 'whether it is still a good alternative for public in the economic crisis conjoncture' are main strands for the evaluation. UK which was the first country to use the model for massive public projects, and so who already started to get the results of the model will be the main reference point along with the extensive reports prepared by the independent public bodies to analize the model.

Keywords: Public-Private partnership, public investments, public finance, off-budget 


\section{Kamu Özel Ortaklığı Modelinin Mali Değerlendirmesi}

\section{Giriş}

Türkiye'de 3 Temmuz 2006 tarihinde Bakanlar Kurulu'nun onayladığı bir yönetmelik ${ }^{1}$ ile kamu sağlık tesislerinin kiralama karşılığ 1 yaptırılması ve tesislerdeki tıbbi hizmet alanları dışındaki hizmet ve alanların işletilmesi karşılığında yenilenmesi olanaklı kılınmıştır. Halihazırda Sağlık Bakanlığı bu model ile 29 kentte sağlık kampüsleri kurmayı hedeflemektedir. ${ }^{2}$ Buna göre ihtiyaç duyulan finansmanı özel sektör konsorsiyumları sağlayacak, hastane binalarını ve tesisleri inşa edecek, bunları idari açıdan yönetecektir. Devlet, proje için gereken araziyi girişimciye bedelsiz temin edecek ${ }^{3}$, tıbbi personeli istihdam edecek, çekirdek sağlık hizmetini sağlayacaktır. Yapılan sözleşmeye

${ }^{1}$ Bakanlar Kurulu Kararıyla yürürlüğe konulan, 3/7/2006 tarih ve 2006/10655 sayıl1, Sağlık Tesislerinin, Kiralama Karşılığı Yaptırılması ile Tesislerdeki Tıbbî Hizmet Alanları Dışındaki Hizmet ve Alanların İşletilmesi Karşılığında Yenilenmesine Dair Yönetmelik.

${ }^{2}$ Kamu-Özel Ortaklığı Daire Başkanlığı'nın internet sitesinden edinilen bilgilere göre, Ocak 2012 tarihi itibariyle, biri yapım aşamasında, dördü sözleşme aşamasında, beşi nihai teklif sürecinde, altısı da ön yeterlik ihalesi yapılmış olan toplam 16 adet sağlık projesi ile süreç başlamıştır.

(http://www.kamuozel.gov.tr/?Islem=YaziKategorileri\&BolumID=7, 2012).

${ }^{3}$ Sağlık Hizmeti Temel Kanunu'nun Ek madde 7'nin ilk fikrasına göre sözleşmeci kendi sahip olduğu taşınmaz üzerine de tesisleri yapabilmektedir. Bu durumda Onur Karahanoğulları'nın girişimcilerin rasyonel davranarak Hazine'ye ait taşınmazların bedelsiz devrini tercih edeceklerine ilişkin vurgusu yerindedir (O. Karahanoğulları, 2011: 187). 
göre tesislerin inşa edilmesi ve alınan hizmetler karşılığında, devlet, özel girişime 25 yıl süreyle kira ödeyecektir.

Finansmanını özel kesimin sağladığı, bağıtlanan sözleşme ile risklerinin kamu ile özel kesim arasında bölüşülmesinin hedeflendiği, Türkiye'de öncelikle sağlık hizmetleri için başvurulan ancak ilerleyen yıllarda başta eğitim olmak üzere diğer kamu hizmetlerine de genişletilmesi beklenilen bu yatırım ve hizmet üretim modeli Birleşik Krallık'ta 1992'den beri gündemde olan tipik bir Kamu Özel Ortaklığı (KÖO) (Public Private Partnership) modelidir.

KÖO modeli, kamunun proje finansmanını vergi gelirlerinden karşıladığ 1 ve kendi kamu personeli ile hizmetleri gerçekleştirdiği klasik kamu hizmet üretim modelini tasfiye ederek hızla onun yerini alması, son derece büyük çapl1, birleşik/entegre projeleri kapsaması, kamunun planlama yetilerini bağlayan uzun süreli sözleşmeleri gerektirmesi nedeniyle dünyada tartış1lan ve kamu kaynaklarının yerinde kullanımı perspektifiyle kapsamlı bir değerlendirmeye ihtiyaç duyulan bir modeldir. Değerlendirmeden kasıt, genellikle modelin kendisi değil, proje bazında yapılan teknik fayda/maliyet analizleri olmaktadır. ${ }^{4} \mathrm{Bu}$ tür fayda maliyet değerlendirmeleri projelere ilişkin olumlu ya da olumsuz sonuçlar üretebilir. Ancak yatırım aşamasının tamamlanmasının 4-5 yıl, hizmet üretim aşamasının ise $20-50$ yıla yayıldığ 1 böylesine uzun süreli projelerin teknik değerlendirmelerinin yoğun varsayımlara dayanacağı ve bunların geçerliliklerinin tartışmalı olacağı açıktır. Üstelik içinde bulunduğumuz kriz konjonktürünün yarattığı ekonomik belirsizlik ve projelere ilişkin varsayımlardaki küçük değişikliklerin bile uzun süreçler için önemli sonuçlar üretmesi, basit modellemelere dayanan fayda/maliyet analizlerini daha da sorunlu k1lmaktadır. KÖO modelinin kamu maliyesi açısından gerçekçi bir değerlendirmesinin ancak tamamlanmış daha önceki deneyimlere referansla ve fayda/maliyet analizinden öteye geçerek kamu kaynaklarının değerinin korunup korunmadığı perspektifiyle yapılabileceğini düşünüyoruz. KÖO modelini 1992'den beri yaygın olarak ve büyük projeler için uygulayan ve dolayısıyla modelin dünyadaki ilk sonuçlarını da almaya başlayan Birleşik Krallık böyle bir değerlendirme için doğru bir referans olsa gerektir. Üstelik Birleşik Krallık'ta çeşitli kamu kurumlarının ve Parlamento komisyonlarının bu projelere ilişkin tarafsız değerlendirme raporları hazırlamış olması bu örneği daha da önemli kılmaktadır.

Geleneksel yatırım modeli yerine KÖO modelinin tercih edilmesinin ardındaki gerekçelerin neler olduğu ve modelin uygulamaları neticesinde bu

\footnotetext{
${ }^{4} \mathrm{Bu}$ noktada belirtmeliyiz ki Türkiye'deki ilgili KÖO projeleri için henüz bu temel
} bilgilere de ulaşılamamaktadır. 
amaçlara ulaşılıp ulaşılamadığı, KÖO modelinin geleneksel modelle karşılaştırmalı olarak düşünüldüğünde kamu için daha maliyetli olup olmadığı, halihazırdaki kriz konjonktüründe KÖO modelinin "hâlâ" ne derece cazip bir model olduğu, alternatif yatırım modellerinin olanaklılı̆̆ gibi temel sorular makalenin konusunu oluşturmaktadır. Bu çalışmada başta Birleşik Krallık Sayıştay'ının (National Audit Office) olmak üzere, Birleşik Krallık Parlamentosu'nun çeşitli komisyonlarının, Hazine'nin, modeli yaygınlaştırmak amacıyla çalışan Partnerships UK, PPPForum gibi kuruluşlarının ve Avrupa Komisyonu'nun desteğiyle kurulan Avrupa Kamu Özel Ortaklığı Girişim Merkezi'nin (EPEC) çeşitli raporları makalenin temel referansları olacaktır.

Buna göre makale beş başlık altında ilgili soruları ele almaya çalışacaktır. İlk olarak, KÖO modelinin genel özellikleri, tanımlayıcı çerçevesi ve modelden beklentiler kısaca ele alınacaktır. İkinci olarak kamu kaynaklarının değeri sorunsalı çerçevesinde KÖO modelinin yarattı̆̆ sorunu ele alınacaktır. Bu başlıkta 2008 ekonomik krizi ile KÖO modelinin artan maliyet sorununa vurgu yapılacaktır. Üçüncü olarak kriz sonrası konjonktürde modelin yapısal bir tanımlayıcısı haline gelen kamu garantileri olgusu da ayrı bir başlıkta incelenecektir. Dördüncü olarak, modelin yaygınlaşmasını sağlayan ancak ilerleyen dönemlerde kamu maliyesi açısından önemli bir probleme dönüşen, projelerin bütçeleştirilmemesi ve bilanço dışında kalması sorunu ele alınacaktır. Beşinci olarak, modelin yarattığı bir diğer sorunlar olarak kamu kesiminin özel danışmanlık şirketlerine artan bağımlılığı, ticari olarak sakıncalı bağlantılar, modelin yarattı̆̆ katılıklar ve çalışma koşullarını yeniden biçimlendirmesi yazıda değinilen son konu olacaktır ve yazı KÖO modelinin genel bir değerlendirmesi ile sonlanacaktır.

\section{Modelin Tanımı}

Kamu Özel Ortaklığı modelinin benimsenmesini sağlayan varsayımlar, özel kesim ile kamu kesiminin yapıları itibariyle farklı uzmanlıklara sahip oldukları, büyük ölçekli yatırımların verimliliğini arttırabilmek için toplam riskin iki kesim arasında bölüştürülebileceği, böylece maliyetlerin azaltılabileceği, hem kamu kesiminin hem de özel kesimin faydalanabileceği bir ortaklı̆̆ın mümkün olduğu şekilde sıralanabilir. Buna göre özel kesimin uzmanlı̆̆ının, finansman riskini iyi yönetebilme ve zamanı iyi örgütleme becerisinden (üretim organizasyon becerisinden) geldiği, kamu kesiminin uzmanlığının ise makro ölçekli planlama yapabilme becerisinden geldiği düşünülmektedir. Modelin bu iki avantajı birleştirip toplam maliyetleri azaltacă̆ 1 öngörülmektedir. Bir diğer önemli özellik ise, proje finansmanının özel kesim tarafından gerçekleştirilmesidir. Bu durum genellikle yanlış biçimde KÖO modelinin, "kamunun cebinden beş kuruş para çıkmadan yatırımların 
yapılmasını olanaklı kılan" sihirli bir model olarak sunulmasına neden olmaktadır. Kamu Özel Ortaklığı (KÖO) modeli halihazırda Avrupa Komisyonu'nun destekleyerek Avrupa Kamu Özel Ortaklığı Girişim Merkezi (European Public Private Partnership Expertise Center- EPEC) isimli bir birim kurduğu, Dünya Bankası'nın desteklediği ve tüm dünyada özellikle kriz öncesi konjonktürde neoliberal politikalar çerçevesinde yaygınlık kazanmış olan bir modeldir ve hızla geleneksel kamu yatırım ve hizmet üretim modelinin yerini almaktadır. ${ }^{5}$

KÖO modelini, bir özelleştirme modeli olarak değerlendirmek mümkündür; ancak geleneksel haliyle özelleştirme modelinden bazı önemli noktalarda farklılaşmaktadır. Özelleştirmeler, kamusal mülkiyetteki üretim araçlarının, menkul ve gayrimenkul değerlerin, özel sermayeye kısmen ya da bütünüyle devredilmesi şeklinde gerçekleşmektedir. Özelleştirmelerin, hem kamunun elindeki mülklerin miktarıyla hem de toplumsal tepkilerle yani meşruiyetle belirlenen sınırları vardır. İşte bu noktada KÖO modelinin günümüzde tüm dünyada gittikçe daha çok gündeme gelmesinin nedenlerinden biri de geleneksel haliyle özelleştirmelerin ekonomik ve politik sınırlarına yaklaşılması olabilir. Çünkü, KÖO geleneksel özelleştirmelerde olduğu gibi, özel sermayeye yeni bir kârlılık ve piyasa alanı açmaktadır ancak KÖO’nın fark1, satış işleminin yani kaynak transferi işleminin daha tesisler ortada yokken sözleşmeye bağlanması ve kamu ile özel arasındaki ticari ilişkinin tesislerin yapım aşamasından başlayarak, işletilmesine ve nihayetinde kamuya devredilmesine kadar geçen son derece uzun bir sürece yayılmasıdır. KÖO modeli ise yatırım ve işletme aşamalarını da kapsamaktadır. Oysa klasik özelleştirme modelinde kamu ile özel sermaye arasındaki ticari ilişki bir seferde gerçekleşmektedir ve bir satış işlemi olarak kalmaktadır.

KÖO modelinde hem çekirdek kamu hizmet üretim yükümlülüğü kamu otoritesinde kalmakta, hem de özel kesim bu üretim alanına dahil edilmektedir. Sadece kamu hizmetinin uygun koşullarla üretiminin sağlanması değil, özel sektörün büyümesinin teşvik edilmesi de modelin amaçları arasında yer almaktadır (NAO, 2011: 13). Model bu anlamda "kamu hizmeti alanının özel

\footnotetext{
${ }^{5}$ Uluslararası Finans Kuruluşu IFC özel yatırım projelerini ve KÖO modeliyle yapılacak projeleri desteklemek için 300 milyar dolar kaynak ayırarak küresel bir kredi finansman mekanizması kurmuştur (Hall, 2009: 6). Avrupa Yatırım Bankası (European Investment Bank) KÖO modelinin en büyük finansörlerinden biridir (Hall, 2008: 8). Avrupa Komisyonu 2006 yllında, Avrupa Bölgesindeki Projeleri Desteklemek İçin Ortak Destek (Joint Assistance to Support Projects in the European Regions) isimli bir kurum kurmuştur. Kamusal olarak finanse edilen kurum AB üyesi ülkeler için KÖO modelleriyle yapılacak projelere ücretsiz danışmanlık desteği sunmaktadır (http://www.jaspers-europa-info.org/index.php/about-us.html, 2011).
} 
girişimcilerle (piyasa ile) ilişkisinde, birinci ve üçüncü tip ilişkinin bir birleşimi olarak dördüncü tip bir ilişki olarak" tanımlanabilmekte, kamunun özel sektörden mal ve hizmet satın almasından farklı olarak özel firmaların "çekirdek kamu hizmeti dışındaki hizmetleri üretmek üzere kendisi veya alt müteahhitlerinin kamu hizmeti alanına uzun süreli” yerleşmektedir (O. Karahanoğulları, 2011: 181) $)^{6}$. Modelde ilgili ortaklık ilişkisi uzun dönemli sözleşmelerle gerçekleştirilir. Kamu Özel Ortaklığında, ilgili kamu hizmeti üretiminin neredeyse tüm aşamaları birden, 20 ile 50 yıl gibi bir süre için tek bir sözleşmede kapsanmaktadır.

Birleşik Krallık bu modeli yaygın ve geniş ölçekli olarak kullanan ilk ülkedir. 1992'de Muhafazakar Parti'nin başlattığı ve esas olarak İşçi Partisi'nin "Üçüncü Yol" politikalarıyla benimseyerek güçlendirdiği Özel Finansman Girişimi modeli (Private Finance Initiative) dünyada KÖO modellerinin en önemli uygulamalarıdır. ${ }^{7}$ Son 15 yılda Birleşik Krallık'taki büyük kamu yatırımlarının neredeyse tamamı bu model ile gerçekleştirilmiş durumdadır. Birleşik Krallık Hazine verilerine göre 56 milyar sterlin değerinde, 600'ün üzerinde proje bu model kapsamında gerçekleştirilmiştir. Bunlar özellikle, hastane, okul ve ulaştırma projelerini kapsamaktadır (http://pppforum.com/projects, 2011). ${ }^{8}$

Özellikle kamu sağlık hizmetinin, KÖO modelinin yoğun olarak uygulandığ1 alan olduğu görülmektedir. Hazine'nin Mart 2011 tarihli KÖO projeleri veritabanından hareketle, KÖO biçiminde yapılan yatırım anlaşmalarının içinde 116 tanesinin Sağlık Bakanlığı'yla ilişkili olduğu ve

${ }^{6}$ Çekirdek hizmetin özel sektörden temin edilmemesi ve kamunun sorumluluğunda kalması nedeniyle ilgili sözleşmeler, eksik imtiyaz sözleşmesi olarak adlandırılmaktadır (O. Karahanoğulları, 2011: 183).

${ }^{7}$ Bundan sonra yazıda, Özel Finansman Girişimi ifadesi, yazının akıcılığını bozmamak için Kamu Özel Ortaklığı olarak kullanılacaktır.

${ }^{8}$ Birleşik Krallık'la karşılaştırıldığında zayıf kalmakla birlikte Avrupa'da da KÖO modeli tercih edilen bir modeldir. Birleşik Krallık'ta 2001-2007 döneminde KÖO projeleri toplam 501 adet ve toplam değeri 42,1 milyar avro, Avrupa toplamında ise 193 adet ve 31,6 milyar avro değerinde gerçekleşmiştir. Avrupa'da KÖO modelinin \%82'si ulaşım ve altyapı yatırımlarından oluşmaktadır. Birleşik Krallık'ta ise projelerin yarıdan fazlası, sağlık, eğitim, yerel yönetim projelerinden oluşmaktadır (Hall, 2008: 4). Birleşik Krallık'ta modelin bundan sonra özellikle enerji ve ulaştırma projelerine yaygınlaşması beklenmektedir. KÖO Forumu isimli kurum, Birleşik Krallık'ta 2011 yılında Hazine'nin açıkladığ 200 milyar sterlin ederindeki orta vadeli kamu altyapı yatırım planı incelendiğinde ve kamu maliyesinin durumu göz önüne alındığında bu yatırımların kaçınılmaz bir şekilde KÖO modeliyle finanse edileceğini tahmin etmektedir (PPPForum, 2011: 7). 
bunların ikisi dışında tamamının halihazırda tamamlandığını ve hizmet vermekte olduğunu görmekteyiz. Sağlık alanındaki sözleşmelerin en uzunu 37 yıllığına olmak üzere, ortalama 30,1 yıllığına bağıtlandığı ve yatırım tutarının 11,9 milyar sterlin olduğu görülmektedir (HM Treasury, 2011).

KÖO modelini hayata geçirmek için kamu kesiminde ilgili Bakanlıklar altında Özel Finansman Birimleri (Private Finance Units) kurulmaktadır. Bunlar, özel kesimle teması kuran, yatırımlar için esasları belirleyen, sözleşmeleri yürüten birimlerdir. Modelin özel kesim ayağında ise KÖO modelinde finansman riskini projeyle sınılandırmak için sermaye ortaklıkları şeklinde kurulan Özel Amaçlı Şirketler (Special Purpose Company) bulunmaktadır. Böylelikle, projenin başarısızlığı durumunda çapraz finansal ilişkilere girilmemekte, risk sadece ilgili proje ve finansman üzerinde kalmaktadır. Özel finansman maliyeti projenin başarısızlığ durumunu ve geri ödenememesi riskini fiyatlandırmaktadır. Projelerin finansmanı, Birleşik Krallık örneğinde $\% 90$ oranında borçlanarak, \%10 oranında da öz sermaye fonlarından karşılanmaktadır (NAO, 2009: 12). Borçlanma ise genellikle uluslararası bankalar aracılı̆̆ıyla gerçekleştirilmektedir.

Modelin uygulanması sırasında kamu kesimi, çeşitli kurumlardan danışmanlık desteği almaktadır. Bunun en önemli nedeni ise özel kesim ile girilen ilişkinin büyük çaplı ve ticari bir ilişki olması ve kamu kesiminde ticari beceriye sahip personelin olmaması olarak görülmektedir. Çeşitli kuruluşlar hem kamu kurumlarına danışmanlık hizmetleri vermekte hem de KÖO modelinin yaygınlaşması için faaliyetler yürütmektedir. İngiltere'de PPPForum ve Partnership UK bu tür kurumların en önemlileridir.

Yazının ilerleyen bölümlerinde modelin burada kısaca sıraladığımız ana özellikleri eleştirel bir çerçevede detaylı olarak ele alınmaya çalışılacaktır. Birleşik Krallık Sayıştayı (National Audit Office), KÖO modeliyle yapılan yatırımları her yıl hazırladığı raporlarla ayrıntılı bir şekilde incelemektedir ve bu raporlardan ulaştığı sonuçlar modele ilişkin eleştirilerin temel çerçevesini çizmektedir. Sayıştay, 2009 yılına kadar konuya ilişsin hazırladığı toplam 72 raporu değerlendirirken KÖO modelinin kamu için yararlı olabileceği ancak bunun mutlak bir zorunluluk olmadığı, KÖO modelinin maliyet ve koşulları incelenmeksizin kabul edilebilir bir model olmadığı sonucuna ulaşmıştır (NAO, 2009). Özellikle kriz sonrası ekonomik koşulların kamu maliyesi açısından etkilerini ve projelerin ticari başarısını incelemek üzere hazırladığ 1 2011 tarihli en son raporunda ise, herhangi bir program ya da proje için özel finansman modelinin gerçek performansının sistematik ve sağlam bir değerlendirmesine ulaşılamadığını belirtmektedir (NAO, 2011). Bu iki sonuç, KÖO modeline ilişkin yaygın kabul gören görüşlerin ve tezlerin Birleşik Krallık Sayıştayı gibi uluslararası düzeyde saygın bir kamu kurumu tarafından açıkça reddedilmesi anlamına gelmektedir. 
Birleşik Krallık Sayıştay'ının bu incelemelerdeki temel referans kriteri ve kurumun amaçlarını da şekillendiren temel kavram, "kamu kaynaklarının değerinin korunması"dır (value for money). Bu kavram, projelerin ticari bir değerlendirmesinden ziyade, kamu maliyesi merkezli olmak üzere, planlama, denetleme, kamu yönetimi perspektifleriyle yapılacak bir değerlendirmeye işaret etmektedir. ${ }^{9}$ Uygulanabilirlik (feasibility) ve maddi olarak karşılanabilirlik (affordability) kriterlerini KÖO modellerinin genellikle karşılayabildiği ancak KÖO modelinin tercih ediliyor oluşunun stratejik gerekçesinin ikna edici bir şekilde ortaya konmadığını, projelerin değerlendirilmesinde kullanılan finansal modellerin hatalarla malul olduğunu, projelerden beklenilen sonuçların açıkça ortaya konmadığını, riskin ölçülmesinde öznel değerlendirmelere başvurulduğunu ve bu nedenle KÖO modelinin daha az maliyetli olduğu sonucuna kolayca ulaşılabildiğini, sağlam bir maliyet analizinin yapılmadı̆̆ını dolayısıyla özel kesim finansmanının kamu kaynaklarının en iyi kullanımı olduğunun kanıtlanamadığını Birleşik Krallık Sayıştay'1 vurgulamaktadır (NAO, 2009: 8, 46).

KÖO projeleri değerlendirilirken sadece mutlak bir değerlendirme yapılmaması yani projenin hayata geçirilmediği hipotetik bir durumla karşılaştırmalı olarak analiz yapılmaması, bununla birlikte projenin hedefine başka modellerle ulaşılabildiği diğer alternatif durumların da (karşı olgusal analiz) incelenmesi ve de ilgili projenin benzer projeler ile karşılaştırmalı olarak değerlendirilmesi gerekmektedir. $\mathrm{Bu}$ noktada Sayıştay, kamu kaynaklarının yerinde kullanılıp kullanılmadığı sorusunun yanıtlanabilmesi için araştırmanın bu üç farklı yöntemi de kapsaması gerektiğini vurgulamaktadır (NAO, 2009: 44). Bu değerlendirme diğer alternatif hizmet üretim biçimlerini ve özellikle de geleneksel hizmet üretim modeli olan kamunun vergi gelirleriyle ve kendi personeliyle hizmet ürettiği alternatif modelleri de içermelidir. Böyle bir değerlendirmenin olmadığı durumlarda Sayıştay'ın vurgusu, KÖO modelinin kamu kaynaklarının en iyi kullanımını sağladığını hükümetin varsayamayacağı yönündedir.

2009 tarihli Birleşik Krallık Sayıştay raporu, incelenen 100'ün üzerindeki projenin \%20'sinin, sözleşmeden ya da uygulamadan kaynaklanan nedenlerle açıkça kamu yararını ihlal ettiğini belirtmektedir (NAO, 2009: 19). Sayıştay, projeler hayata geçirilip hizmet üretimi başladığı noktada, projenin

\footnotetext{
9 "Value for money" kavramı için burada önerdiğimiz Türkçe karşıllı "kamu kaynaklarının değerinin korunması" olmuştur. Kavram, "kamu kesiminin harcamalardan tasarruf etmesi" anlamını da içermekle birlikte metinde de belirtilmeye çalışıldığı gibi basitçe iktisadi bir referanstan ziyade planlama denetleme, kamu yönetimi perspektiflerine referansları da içermektedir.
} 
kamu kaynaklarının yerinde kullanımı adına bütünlüklü bir değerlendirmesinin yapılması, bu modelin hedeflenen faydayı sağlayıp sağlamadığının araştırılması, ilerleyen yatırımlar için bu modelin tercih edilip edilemeyeceğinin sorgulanması gerektiğini ancak bunları gerçekleştirmek için hiçbir kamu otoritesinin formel olarak görevlendirilmediğini vurgulamakta ve eleştirmektedir (NAO, 2009: 44). KÖO projelerinin ihaleden yatırımın gerçekleştirilmesi ve hizmet üretim aşamaları ve nihayetinde varlıkların kamuya teslimi aşamalarına kadar geçen süre zarfında sözleşme koşullarının sağlanıp sağlanmadığının denetlenmesi için kamu kesiminde yeterli nitelikte ve sayıda personelin bulunmaması ve ilgili personellerin de sürekliliğinin olmaması önemli bir dezavantaj olarak vurgulanmaktadır.

\section{Maliyet Sorunu}

Projenin finansman maliyetiyle birlikte toplam maliyeti nihai kertede yıllık kira ödemesi şeklinde kamu otoritesince ya da hizmetten yararlananlar tarafindan hizmet bedeli olarak ödenmektedir (NAO, 2009: 12). Bu nedenle modelin maliyet sorunu kamu için son derece önemli bir sorundur. Maliyet, firmaya ait, özel ve ticari bir risk ya da sorun olmaktan öte, kamusal bir risk ve sorun olarak düşünülmelidir.

Hazine'nin Mart 2011 tarihli KÖO projeleri veritabanından hareketle yaptığımız hesaplamalara göre, 1998 yılından itibaren, sağlık alanındaki projelerin geri ödemesinin tamamlanacağı 2048 yılına kadar geçen süre zarfında ödenmiş ve ödenecek olan kira bedellerinin toplamının 73.697 milyon sterlin, yatırımların tutarının ise 11,9 milyar sterlin olduğu görülmektedir (HM Treasury, 2011). Yani kamu kesimi 11,8 milyar sterlinlik yatırım için ortalama 30,1 yıl süreyle geri ödemek üzere 73,6 milyarlık harcama yapmaktadır. Bu ise 30,1 yıl için birleşik faizden \%7,6'lik bir getiri anlamına gelmektedir, ki 2011 'in son altı ayı için 30 yıllık takas oranı olan \%4,35 ile karşılaştırıldığında (http://www.swap-rates.com, 2011) son derece yüksek bir orandır.

Kamu kesimi, teorik olarak özel kesimin hem kredi maliyetlerini hem de sermaye getirisini yani net kârlarını karşılamalıdır ki özel kesim bu ortaklık ilişkisinde yer alabilsin. Modelde kamu kesiminin yatırımları kendisinin üstlenmemesi nedeniyle özel firmaya net değer transferi (özel firmanın kredi maliyeti ve kârı kadar) yapan bir konumda olacağı açıktır. Modelin bu gerçekliğe rağmen tercih edilmesinin ardındaki varsayım, ortaklıkla elde edilecek verimlilik artışının bu transferi telafi edecek ölçüde olacağıdır. Oysa ki, modelin özünde böyle bir verimlilik artışını garanti edecek hiçbir mekanizma yoktur.

David Price'nin vurguladığ üzere, özel kesimin verimlilik artış1 sağlayacağı varsayımı, tam rekabetçi piyasa ekonomisi koşullarında yani iflasın 
da bir olasılık olarak gündemde olduğu koşullarda geçerli olabilir. Randımansız olan, verimliliği yakalayamayan elenecektir. Oysa ki KÖO modelinde geçerli olan sözleşmelere konu olan projelerin çapı ve önemi o kadar büyüktür ki başarısızlığa uğraması, hükümetlerin buna izin vermesi neredeyse imkansızdır (Price, 2009). Yani bahsedilen tam rekabet koşulları varsayımsal düzeyde geçerli olabilmektedir.

$\mathrm{Bu}$ yatırım modellerinin en problemli kısmı, özel sektörün piyasadan borçlanma maliyetinin devletin borçlanma maliyetine göre yüksek oluşudur. Eski Maliye Bakanlarından Norman Lamont, Private Finance Initiative kitabında bu tür projelerde özel kesim finansmanının her zaman daha maliyetli olduğunu kamu kesiminin krediye ulaşma imkanının ise her zaman daha düşük olduğunu vurgulamaktadır (aktaran Gosling, 2003: 3, 21). 2006 yılında KÖO projesi için uluslararası kredi derecelendirme kuruluşları BBB+ yani yüksek risklinin bir üstü olarak notlandırılırken, Avrupa'da genel olarak devletlerin aldığ1 not AAA'dır (McKee, vd. 2006: 891). Tüm 20'inci yüzyıl için bir inceleme yapıldığında Birleşik Krallık’ta özel kesimin borçlanma maliyetinin $\% 5,5$ ile \%7,5 arasında değiştiği, kamu kesiminin borçlanma maliyetinin ise $\% 2,5$ oranında gerçekleştiği; ABD için ise kamu kesiminin borçlanma maliyetinin özel kesime göre \%35 oranında daha ucuz olduğu görülmektedir (Hall, 2008: 18). Finansman yollarının büyük bir bölümü banka kredisi şeklindedir, tahvil ve bono ihracı ile finansman ise istisnai olarak kullanılabilmektedir (Hoicka, 2007). Bu durum ise kredi maliyetiyle birlikte yüksek işlem maliyetlerinin de işin içine girmesine neden olmaktadır.

Birleşik Krallık Sayıştayı, KÖO modelinin finansman maliyetinin geleneksel kamu hizmet üretim modellerinin maliyetine göre daha yüksek olmasının altı nedenini şu şekilde sıralamaktadır: i) NAO'in hesaplarına göre özel sektörün krizden önce borçlanma maliyeti Birleşik Krallık borçlanmasının 60 ila 150 baz puan üzerindedir. ii) Risk maliyeti daha yüksektir, \%10 ile 15 arasındaki bir getiri anlamına gelmektedir bu risk. iii) Üstelik risklere karşı korunmak için genellikle yatırımcılar ve kreditörler bir ihtiyat fonu talep etmektedirler, bu fonun oluşturulması ve yönetilmesi de geleneksel hizmet üretim modellerinden farklı olarak bir maliyet yaratmaktadır. iv) KÖO modelinde finansmanın sağlanması aşamasında (örneğin swap ücretleri gibi) işlem maliyetleri de işin içine girmektedir. v) İhale süreci uzun ve maliyetli bir süreçtir, karmaşıktır. vi) Sözleşmenin uygulanma aşamasında da maliyetler söz konusudur; özel amaçlı şirketin ve taşeronluk ilişkilerinin denetlenmesi gerekmektedir (NAO, 2009: 22). 


\section{Kriz Sonrası Dönemde Maliyet Artmaktadır}

KÖO modeline ilişkin ortaya konulan maliyet analizlerinin çoğu 2008 krizi öncesi koşullara ilişkindir. Sayıştay, uluslararası iktisadi krizin ardından Birleşik Krallık için borçlanma maliyetlerinin \%20-33 oranlarında arttığını ve bu koşullarda KÖO modelinin eskisi kadar uygun bir model olamayabileceğini vurgulamaktadır (NAO, 2011: 8, 9). Dünya Bankası'nın özel kesimi finanse eden kuruluşu olan Uluslararası Finans Kuruluşu (IFC), krizle birlikte ortaya çıkan finansman sorunu nedeniyle 110 milyar dolar değerinde KÖO projesinin iptal edilebileceği, halihazırdaki 70 milyar dolarlık projenin de risk altında olduğunu tahmin etmektedir (aktaran Hall, 2009: 6).

Krizin etkisini daha iyi görebilmek için maliyetlerin bileşenlerini biraz daha detaylı inceleyebiliriz. İşlem maliyetlerini bir kenara koyacak olursak, sabit oranlı finansman maliyetinin iki bileşeni vardır: uzun dönemli takas faiz oranı (swap rate) ve bu uzun dönemli takas faiz oranının üzerine eklenen risk primleri. Bunlar ise takas riski (takas kredi marjı) ve kredi kullanan şirketin riskinden oluşmaktadır ve Sayıştay, literatürdeki pek çok çalışmanın bu takas kredi marjını hesaba katmadığını vurgulamaktadır (NAO, 2009: 31). 2008'in sonunda yani kriz öncesinde uzun dönem takas oran1 \%3,4 iken, kriz sonrasında \%4,1'e yükselmiştir. Hâlihazırda bu oran \%4,35'tir. Sayıştay'ın hesaplarına göre, kriz öncesinde KÖO modelinde özel kesim borçlanma faiz maliyeti, devletin borçlanma maliyetinin (25 yıllık GILT faizinin) \%1 ile \%1,6 üzerindeyken kriz sonrası dönemde bu oranlar \%1,4 ile \%2,5 düzeylerine yükselmiştir (NAO, 2009: 32). 2009 yılında Sayıştay’ın yaptığı tahminlere göre 25 yıllık ve 100 milyon sterlin değerindeki bir finansman için 2007 yılına göre özel kesimin borçlanma maliyeti kamu kesimine göre 6,3 milyon sterlin daha yüksektir (NAO, 2009: 33).

Tarihsel olarak baktı̆̆ımızda KÖO modelinin finansman maliyeti 2000'ler boyunca ve krize kadar piyasalarda likiditenin ve kredi veren kuruluşlar arasındaki rekabetin artması ile birlikte zaman içinde azalmış, \%0,85 ile \%1,25 oranlarına kadar düşmüştür (NAO, 2009: 32). Kriz sonrası dönemde bankacılık sektörünün içine düştügü daralma ile takas oranı ve takas kredi marj1, tipik bir inşaat projesi için ortalama $\% 2,5$ olmak üzere $\% 1,8$ ile $\% 3,5$ arasında artmıştır. Bununla birlikte bankaların krizle birlikte yükselttikleri işlem ücretleri de düşünüldüğünde özel kesimin borçlanma maliyetlerinin hızla yükseldiği görülmektedir. Kriz sonrası konjonktürde işlem ücretlerinin \%1'den $\% 2,5$ 'lere yükseldiği görülmektedir. Bu durum finansman maliyetinin kriz öncesi döneme göre \%20 ile \%33 oranında artması anlamına gelmektedir.

Artan finansman maliyetleri, projenin maliyetini arttırmakta ve bu ise kamu için özel firmalara daha yüksek kira ödemesi anlamına gelmektedir. İngiltere'de M25 otoyol projesinin kamuya maliyetinin kriz sonras1 dönemde 
\%24 oranında arttığı hesaplanmaktadır. Sayıştay açıkça, daha önce bakanlıkların avantajlı olarak gördükleri modelin avantajlarının kriz ile birlikte ortadan kalktığını vurgulamaktadır (NAO, 2011: 14).

Birleşik Krallık Sayıştay’ının değerlendirmesine göre 2008 krizinin KÖO projeleri üzerindeki etkileri önümüzdeki 30 y1llık dönem boyunca hissedilmeye devam edilecektir. Krizin halihazırdaki projelere olan etkisinin 1 milyar sterline yakın ek bir maliyet olduğu hesaplanmaktadır. Genellikle projelerin uygulanma aşamaları kredi ilişkisi bakımından en az riskli ve dolayısıyla en az maliyetli dönem olmasına rağmen krizin maliyet arttırıcı etkilerinin bu uygulama aşamasına da yayılması, işletme evresinin de maliyetli hale gelmesi olasidır (NAO, 2011:28).

Böyle bir kriz konjonktüründe, ilerleyen y1llarda borçlanma maliyetinin düşeceği beklentisi ile proje finansmanı için daha kısa vadeli borçlanmalar tercih edilebilmektedir. Ancak bu tercih, piyasa koşullarına ilişkin riskli bir beklentiye dayanmaktadır; vade dolum tarihinde faizlerin yükselmesi durumunda proje finansmanı olumsuz etkilenecektir. Bir diğer husus, vadelerin kısaltılmasının borçlanmanın maliyetini gereksiz yere arttırmasıdır. Yeniden finansman daha uygun koşullarla gerçekleşse bile kamu otoritesi açısından sorunlu bir başka nokta daha vardır. Kamu kesiminin bu maliyet düşüşünden yararlanabilmesi tamamen KÖO anlaşmasının şartlarına bağlıdır. Eğer yeniden finansman kazancının kamu ile özel arasında bölüşülmesi sözleşmeye konu edinilmemişse tüm kazanç özel firmada kalacaktır. Birleşik Krallık’ta 1 Kasım 2008 sonrasında yapılacak KÖO sözleşmelerinde yeniden finansman kazançlarının \%70'inin kamuda kalması kararı alınmıştır (NAO, 2009: 32). Sayıştay'ın tespitine göre daha önce yapılan yeniden finansmanlarda kamunun elde ettiği kazanım oranı son derece düşüktür. Örneğin Norfolk ve Norwich KÖO Hastanesinin 116 milyon sterlin ederindeki yeniden finansman kazancının sadece \%29’u Ulusal Sağlık İdaresi Tröstünce paylaşılabilmiştir.

\section{Ölçek Getirisinden Kamu Yararlanamamaktadır}

Kamu Hesapları Komitesi, Sağlık Bakanlı̆̆ı'nın KÖO sözleşmelerinde, kamunun satın almadan gelen ölçek gücünün iyi bir şekilde değerlendirilmediği sonucuna varmıştır. Sözleşme pazarlıklarının merkezi bir şekilde yapılmamış olması, kamunun satın almadan gelecek olan gücünün ve dolayısıyla vergi gelirlerinin iyi bir şekilde kullanılmadığını göstermektedir (NAO, 2011: 27). $\mathrm{Bu}$ sorun özellikle yerel yönetimlerin yatırımları için daha da belirgin hale gelmektedir. Komite, Birleşik Krallık'ta bağıtlanan 700 civarındaki sözleşmenin çoğunun yerel düzeydeki projelere ilişkin olduğunu ve bunun ise yemek hizmetleri, temizlik hizmetleri ve bina bakım onarım hizmetlerinde kamunun ölçek ekonomisinden yararlanamaması anlamına geldiğini, yani 
modelin bir verimlilik kaybına yol açtı̆̆ını, toplamda devletin yarattığ bu kadar büyük bir piyasanın ölçek getirisinden kamunun da yararlanabilmesi için formel mekanizmaların geliştirilmediğini vurgulamaktadır (NAO, 2011: 9).

NAO, KÖO projelerinin sadece ilgili bakanlıkların ve kurumların inisiyatifine bırakılması ve bağımsız kamu kurumları tarafından eleştirel perspektifle araştırılıp değerlendirmesi gerektiğine vurgu yapmaktadır (NAO, 2011: 20). NAO'ya göre ilgili durumda çok daha cazip bir alternatif model söz konusuyken örneğin Otoyollar Ajansı, geleneksel yatırım modeli ile maliyetlerde yaklaşık 1,1 milyar sterlin tasarruf sağlayabilecekken, KÖO modeliyle devam etme kararı alabilmektedir (NAO, 2011: 20).

\section{Projelerin Zamanında ve Bilanço Dahilinde Bitirilememesi}

Birleşik Krallık Sayıştay raporuna göre, 2003-2008 döneminde tamamlanan KÖO projelerinde zamanında bitirilebilenlerin oranı \%69, sözleşmedeki rakamlar dâhilinde tamamlanan projelerin oranı ise $\% 65$ tir (NAO, 2009: 7). Yani \%31 ile \%35 arasında bir başarısızlık söz konusudur.

Birleşik Krallık Sayıştay'ının hesaplarına göre sözleşme imzalanıp inşaat aşamasına geçildiğinde karşılaşılan fiyat artışlarının büyük bölümü kamu otoritesinin gündeme getirdiği yeni isteklerden kaynaklanmaktadır (NAO 2009: 26). Bu durum projelerin büyük boyutlu ve girilen ilişkinin karmaşık ve uzun soluklu yapısı nedeniyle maliyet-fayda analizinin ne derece zor olduğunun da bir göstergesidir. Kamu otoritesi, sözleşme ile birlikte son derece uzun bir dönem için orta vadeli yatırım planlamasını yapıyor olduğu için çeşitli nedenlerle projenin içine yeni unsurlar eklenmesine gereksinim duyulabilmektedir. $\mathrm{Bu}$ da maliyet yaratmaktadır. Bununla birlikte fiyat artışlarının \%10 gibi bir bölümü ise kamu otoritesinin değişiklerinden değil diğer nedenlerden kaynaklanmaktadır. Yani çevresel riskler, izin belgelerinin tamamlanması, arazinin satın alınıp tahsis edilmesi gibi karşılaşılan risklerden kaynaklanan fiyat artışları genellikle kamunun üzerinde kalmaktadır (NAO, 2009: 26).

\section{Maliyetlerin Zamansal Dă̆ılımı ve Tesislerin Bakım Onarım Sorunu}

Kamu otoritesinin kira ödemesini tesisleri teslim aldığ 1 tarihten başlatması beklenilir. Yatırımın zamanında ve bütçe dâhilinde tamamlanmasını kontrol etmenin yollarından birisidir bu. Ancak bu durum modelin yapısal 
özelliği değildir, bağıtlanan sözleşmenin içeriğine göre değişebilir. ${ }^{10}$ Birleşik Krallık'taki uygulamada firmaya, sözleşmedeki inşaatlar ve tesisler tamamlanıncaya kadar geri ödeme yapılmamaktadır. Kira ödemesi hizmet üretiminin başladığı anda yapılsa bile sadece inşaat aşamasındaki risklerin değil, hizmet üretim aşamasındaki risklerin de kontrol altına alınması gerekmektedir. Kamu otoritesi, hizmetin kalitesinin belli standartların altında kalması durumunda firmaya maddi cezalar uygulayabilir; ancak bunun için de ciddi bir kamu denetimi gerekmektedir ki bu da fazladan bir maliyet anlamına gelmektedir.

Projede, tesislerin/varlıkların yönetimi de önemli bir sorun oluşturmakta ve kamu için dolaylı bir maliyet unsuru yaratmaktadır. KÖO modellerinde varlıklar sözleşmede belirtilen sürenin ardından kamuya devredilmektedir. $\mathrm{Bu}$ nedenle varlıkların ilgili sözleşme süresince iyi bir şekilde yönetilmesi hem hizmetin kalitesinin, hem de kamu kaynaklarının yerinde kullanımının bir gerekliliğidir. KÖO modelinde kamu otoritesinin ödeyeceği kira, bakım onarım maliyetlerini de karşılayacak şekilde belirlenir ancak özel firma inşaat ve varlık yönetimi arasındaki maliyet dengesini iyi kuramayabilir; örneğin ilk karşılaşılan inşaat için maliyetlerin artmasına ve hizmet üretimi için gerekli olan kaynakların azalmasına neden olan bir dengesizlik yaratabilir (NAO, 2009: 26).

Geleneksel kamu hizmeti üretim modelinde ekonomik olarak dar zamanlarda bakım onarım harcamalarının kolayca kısıldığı ve bunun ilerleyen dönemlerde daha büyük maliyetler yarattığı düşünülmektedir. Özellikle kamu sermaye yatırımları için kaynak ayrıldığı ancak bakım onarım masraflarının çekirdek hizmet üretim gelirlerinden karşılandığ 1 durumlarda kamu için toplam maliyet artışı daha da yüksektir ve bu durumda bakım onarım harcamaları iyice birikebilmektedir. KÖO modelinde kamu otoritesi, ilgili varlıkların bakım onarım giderlerini karşılayacağını kabul etmektedir. Sayıştay'ın raporuna göre bu durum genel olarak, daha yüksek bir bakım onarım maliyeti ve daha az bir bütçe esnekliği anlamına gelmektedir. Bununla birlikte bakım onarım faaliyetlerinin birikmesinin ve ilerleyen dönemlerde daha büyük maliyetler olarak geri dönmesinin önüne geçileceği beklenmektedir. Ancak Sayıştay yine de bu durumun, toplam sözleşme süresi zarfınca ortaya çıkacak maliyetleri azaltmasının kesin olmadığını vurgulamaktadır (NAO, 2009: 26).

Kamu Hesapları Komitesi'nin raporuna göre, KÖO modelinin temel özelliğinin bina onarım ve bakım hizmetlerinin yüksek standartta sağlanması

${ }^{10}$ Türkiye'de sağlık alanındaki KÖO uygulamalarına ilişkin önemli bir problem, kamunun özel girişime kira ödemelerini ne zaman başlatacağının yasada açıkça belirtilmemiş olmasıdır (O. Karahanoğulları, 2011: 189) 
olduğu varsayılırken durumun hiç de böyle olmadığı görülmektedir. Ulusal Sağlık İdaresi Tröstünde yapılan araştırma kurumların \%20'sinin özel firmanın sunduğu bina bakım onarım hizmetlerinden memnun olmadığını ortaya koymaktadır. Temizlik ve yemek hizmetleri sözleşme sürecinde Sayıştay'ın değerlendirmesine tabii iken, bina bakım onarım hizmetlerinin dışarıda bırakıldığ1 görülmektedir. Bakım onarım hizmetlerinin rekabetçi olup olmaması ve niteliği, sözleşmenin feshi için genelde bir gerekçe olarak görülmemektedir (NAO, 2011:28).

\section{Modelin Kamu Gelirlerini Tahrip Edici Boyutu}

KÖO modelinde, özel girişimcilerin, çeşitli yenilikler yaratarak toplam proje maliyetini düşüreceği varsayılmaktadır. Bu yenilikler sadece teknolojik olmak durumunda değildir. Politik düzenlemeler de maliyet düşürücü araçlardan birisi olabilir. Kamu kesiminin teşvik ettiği yeniliklerden biri, karma tüccar statüsü (composite trader status) uygulamasıdır. Buna göre yüklenici firmanın vergi yükü düşürülerek projenin toplam maliyetlerin azaltılması ve dolayısıyla kamunun proje için yapacağı geri ödemenin de düşürülmesi beklenilmektedir.

Yöntem yüklenici firmanın devlete başvurarak karma tüccar statüsüne geçirilmesi ve firmanın proje sırasındaki maliyetlerin neredeyse tamamını vergi matrahından düşmesi şeklindedir. Böyle bir statünün elde edilmesi ile birlikte proje tasarım, inşaat ve bakım onarım maliyetleri, sabit sermaye yatırımı yerine vergiden düşebilecek cari harcama olarak görünmektedir (Black, 2003). Buradaki argümanın geçersizliği son derece açıktır. Maliyetler ancak kamunun gelirlerinde tahribat yaratılarak düşürülebilmektedir.

\section{İkincil Yatırım Piyasasl}

KÖO projeleri ikincil bir yatırım piyasası oluşturmaktadır. KÖO modelinde yatırımı gerçekleştiren özel şirketle, diğer özel yatırım firmaları arasında yatırımların bir kısmının alınıp satılmasını sağlayan ikincil piyasaların geliştiği görülmektedir. Bazı firmaların yatırımlarının getirisini projenin örneğin inşaat aşamasının bitiminde almak istediği bazılarının ise projenin sadece işletme aşamasına ilişkin yatırım yapmak istediği görülmekte, ikincil piyasada yatırımların alınıp satılması ile bu sağlanabilmektedir. Küresel ölçekte örneğin emeklilik fonlarından oluşan özel yatırım fonlarının çeşitli KÖO projelerinden oluşan portföylere yatırım yaptıkları görülmektedir. Sayıştay, ilgili projelerin bu tür ikincil piyasa ilişkileri nedeniyle finansörlerinin değiştiğine ve devreye giren bu yatırımcıların ticari saiklerini kamu otoritesinin anlamlandırması gerektiğine vurgu yapmaktadır (NAO, 2009: 58). Bu yatırımcılar portföylerini kar amacıyla yönetmektedirler ve yaptıkları 
yatırımların getirisinin artması için yatırımcıların projenin işletme maliyetlerinin düşürülmesine ya da sözleşmenin işletilmesi aşamasındaki türlü düzenlemelere ilişkin çıkarlarının olduğu görülmektedir. $\mathrm{Bu}$ tür ikincil piyasalarda projenin hisseleri yani yatırımlar el değiştirirken elde edilen kazançlardan kamu kesimi herhangi bir pay alamamaktadır. Standart KÖO sözleşmelerine bu tür kazançların kamu ile paylaşılacağı konusunda bir madde konulmamaktadır (NAO, 2009: 58). Ayrıca Birleşik Krallık'ta 2006 itibariyle, faaliyette olan KÖO projelerinin \%40'ında mülkiyet değișimi söz konusu olmuş ve projeler yeni mülk sahiplerine satılırken yarısında yeniden finansman gerçekleşmiştir. Bu el değiştirmeler sonucunda mali şirketlerin egemenliğinin arttığ1 görülmüşsür (Hall, 2008: 5).

\section{Maliyet Sorununa İlişkin Bazı Ampirik Veriler}

Avrupa Yatırım Bankası'nın Avrupa çapında yaptığı bir çalışmaya göre KÖO modeli ile yapılan otoyol yatırımlarının kamunun geleneksel yatırımlarına göre \%24 daha maliyetli olduğu tespit edilmiştir (aktaran Hall, 2008: 19). Kanada'da Ontorio bölgesi Sayıştay'1, KÖO ile yapılan hastane projesinin, geleneksel kamu yatırım modeli ile gerçekleştirilmiş olsa idi 50 milyon dolar daha ucuza mal edilebileceğini belirmiştir (Hall, 2009: 5). Fransa'da şebeke sularının dörtte üç oranında KÖO modeli ile özel sektör tarafindan sağlandığı bir model uygulanmaktadır. Bu modeli uygulayan belediyelerde 2004 y1lında yapılan bir araştırmaya göre, suyun fiyatının \%16,6 oranında daha yüksek olduğu tespit edilmiştir (Hall, 2008: 22). Tekel niteliğindeki hizmet alanları KÖO modeli ile özel kesime geçtiğinde, fiyatlandırma davranışı da değişmektedir. 2006 yılında büyük KÖO hastanelerinin yarısından fazlasının finansal sorunlar yaşadığı, KÖO modelinde olmayan hastanelerin ise sadece dörtte birinin benzer finansal zorluklar içinde olduğu tespit edilmektedir (Pollock vd., 2011: 419). Sayıştay'ın incelemelerine göre, hastanelerin \% $\% 2$ 'si, KÖO modelinin geri ödeme maliyetlerini karşılayabilmek için doluluk oranlarını tavsiye edilen sınırların üzerine çıkarmak zorunda kalmıştır (aktaran Pollock vd., 2011: 419). Bu da modelin sadece orta vadede kamu kesiminin maliyetlerini arttırmakla kalmadığını ve çekirdek hizmet üretim kalitesini de doğrudan etkilediğini açıkça ortaya koymaktadır.

\section{Kamu Garantileri}

2008 kriziyle birlikte, özel şirketlerin finansal piyasalardan borçlanması güçleşmiş, maliyetler artmış ve modelin sürdürülebilirliği için KÖO modeline ilişkin daha önce de örtük olarak var olan bir olgu açıkça modelin bir parçası 
haline gelmeye başlamıştır. Bu olgu, finansal piyasaların KÖO projelerine kredi verirken artık devlet garantisi aramasıdır.

Mayıs 2011 tarihinde Avrupa KÖO Uzmanlık Merkezi (EPEC) Kamu Özel Ortakllklarında Kamu Garantileri isimli bir raporla standart risk paylaşımının KÖO modelinin tüm faydasını ortaya çıkaramadığını bu gibi durumlarda kamu garantilerinin işlevsel olacağı görüşünü vurgulamıştır (EPEC, 2011: 5). Rapordan anlaşılan o ki kamu garantisine ihtiyaç duyulan bu durumlar 2008 krizi sonrasında artık genelleşmiş ve modelin yapısal bir birleşenine dönüşmüştür. ${ }^{11}$

EPEC'e göre kamu garantilerinin amacı: KÖO piyasasında güven ortamını sağlamak, finansman modeli için gerekli olan yatırımcıları piyasaya çekebilmek, kamunun piyasaya karşı sorumluluklarını yerine getiren bir pozisyonda olduğunu göstermek (demonstrate government commitment), pazarlık/durum analizi/alınması gereken önlemlerden oluşan sözleşme sürecini kısaltmak ve yatırımların hızla gerçekleştirilmesini sağlamak, büyük çaplı ve marka niteliğindeki yatırım projelerinin başarısızlığa uğraması riskine karşı KÖO piyasasının güvenini sağlamak, ulaşılan kredi miktarını genişletmek, projenin finansman maliyetini düşürmek, finansal mekanizmaları etkin kullanmak, daha pahalı olan tahvilleri daha ucuz olan borçla değiştirmek; finansman riski ile karşılaşılan ve yarım kalan projelerin tamamlanmasını sağlamak, kamu garantileri sayesinde sermaye piyasasına başvurmayı, bankalardan borçlanmaya göre daha cazip hale getirmek yani KÖO modeli ile sermaye piyasasını ilişkilendirmektir (EPEC, 2011: 7-8).

\section{Garantinin Biçimleri}

Borç geri ödeme garantisi, en yaygın olan garanti biçimidir. Özel firmanın aldığ kredilerin geri ödenme riski, tam ya da kısmi olarak kamu tarafından garanti altına alınabilir. Garanti, özel șirketin iflası durumunda, kamunun kreditör kuruluşa borcun tümünü faiziyle birlikte (hızlandırılmış ödeme) ya da kalan taksit kompozisyonunu bozmadan iflas anındaki ilgili taksit ödemesiyle başlayarak geri ödemesi biçiminde olabilir (EPEC, 2011: 13). ${ }^{12}$ Garantinin devreye girmesi durumunda hukuksal olarak nasıl sınıflandırılacağ 1

${ }^{11} \mathrm{KÖO}$ modelinin kamu kesimi yatırımları için alternatifsiz tek model olduğu düşüncesinin bu raporun ardındaki örtük varsayım olması ve raporda geleneksel kamu yatırım modellerine hiçbir şekilde alternatif model olarak referans verilmemesi şaşırtıcıdır.

${ }^{12}$ Borç garantisine önemli bir örnek, EIB ve Avrupa Komisyonu tarafindan kurulan Trans-Avrupa Ulaşım Ağı Projesi için Borç Garanti Aracı'dır (The Loan Guarantee Instrument for Trans-European Transport Network Projects). 
ise ayrı bir sorundur. Garantiler iflas eden özel firmanın borcunu kapatmaya yönelik olabilir ya da ona yapılan karşılıksız yardım şeklini alabilir. Yatırımlara başlanırken alınan borçların geri ödemesi eğer projeler tamamlanmadan başliyorsa, özel firmanın yeniden finansmana başvurması gerekmektedir. $\mathrm{Bu}$ yeniden finansman aşamasında özel firmanın darboğaza girmesi durumu için de ayrıca bir kamu garantisi söz konusu olabilir (EPEC 2011: 14).

Kredi geri ödeme garantisinin dışındaki bir diğer önemli garanti türü, genellikle ulaştırma alanında yapılan hizmetler için geçerli olanı gelir garantisi ya da hizmet kullanım garantisi yani talep garantisidir. Talep riski normalde özel şirkette kalması gereken bir işletme riski iken kamu kesimi bunun en azından bir kısmını garanti altına alarak, riski ortadan kaldırabilir. EPEC bu tür garantilerin doğrudan kredi verenlere değil, özel firmaya yöneldiğini ve kredi veren şirketin riskini tam anlamıyla kapsamadığını vurgulamaktadır (EPEC 2011: 10). Benzer şekilde özel şirketin işletmedeki performansından bağımsız olarak kamunun alım fiyatının belli bir minimum seviyenin altına düşmeyeceğine ilişkin "fiyat garantisi” de söz konusu olabilmektedir (EPEC 2011: 15). ${ }^{13}$

Otoyol veya köprü gibi hizmet alanlarında KÖO modelinin yarattığı maliyetler nihai olarak tüketiciye yansıtıldığında, tüketiciler bu hizmetlerden yararlanmamayı tercih edebilmekte böylece yatırımlar işlevsiz hale gelebilmektedir. Bu durum talep riskine bir örnektir. Polonya'da bir otoyol ve İskoçya'da bir köprü için aşırı ücretlendirme dolayısıyla kullanıcı sayısı beklenenin altında kalmış ve ekonomik durgunluğun da etkisiyle kazancı düşen şirket için hükümet ilave fonları devreye sokmuş ve aradaki farkı kapatmak zorunda kalmıştır (Price 2009).

Sözleşmenin bitimi noktasında, genellikle varlıklar tamamen yıpranmamaktadır, bu noktada kamu aldığı varlıkların karşılı̆̆ını özel firmaya ödemeyi garanti edebilmektedir (residual value payments) (EPEC 2011: 16). Bu da bir diğer kamu garanti türüdür.

Kamu garantilerinin en bilinen uygulaması Metronet örneğinde görülmüştür. İhale aşamasında Ulaştırma Bakanlığı, Londra Metrosu'nun yenileme ve yatırım ihalesini kazanan Metronet firmasının kreditörlerine borçların \%95'inin Londra için Ulaşım (Transport for London) tarafından garanti altına alındığını belirtmiştir. Böylece kamu, KÖO projesinin finansörlerine sadece $\% 5$ 'lik bir risk bırakmıştır. Şirket iflas ettiğinde Bakanlık Londra için Ulaşım'a, Metronet'in finansörlerine verdiği garantiyi

\footnotetext{
${ }^{13}$ Fransa'da "cession de creances" ve Almanya'da "Forfaitierungsmodell" bu tür
} garantiler vermektedir. 
karşılayabilmesi için 1,7 milyar sterlin ödeme yapmak zorunda kalmıştır. Sayıştay'ın bu proje için yaptığı hesaplamalara göre vergi mükelleflerine böyle bir garantinin doğrudan maliyeti 170 ile 410 milyon sterlin olarak gerçekleşmiştir (NAO 2009: 24).

\section{Bilanço Dışılık ve Veri Eksikliği}

Yeni bir kamu yatırım ve hizmet üretim modeli olarak KÖO modelinin kamu kesiminde hızla yaygınlaşmasının ve Birleşik Krallık örneğinde olduğu gibi başat model haline gelmesinin ardındaki nedenlerden en önemlisi, kamunun yükümlülüklerini bilanço dışında tutabilmesi olmuştur. Kamu borçlanma ve açık oranlarının uluslararası anlaşmalarla sınırlandırıldığ 114 , uluslararası finansal kuruluşlar tarafindan kamu kesimi mali performansının izlendiği bir dönemde, kamu yükümlülüklerinin bilanço dışında tutulabilmesi, modelin sunduğu önemli bir esneklik olarak ortaya çıkmaktadır. ${ }^{15}$

Hazine'nin Mart 2011 tarihli KÖO projeleri veritabanından hareketle KÖO biçiminde yapılan yatırım anlaşmalarının 116 tanesinin Sağlık Bakanlığı'yla ilişkili olduğu ve bunların ikisi dışında tamamının halihazırda tamamlandığını ve sadece 350 milyon sterlin ederindeki 7 projenin Birleşik Krallık Muhasebe Standartlarına göre (UK-GAAP) bilanço içi, 11,5 milyar sterlin değerindeki toplam 109 projenin ise bilanço dışında kaldığ 1 görülmektedir (HM Treasury, 2011). Birleşik Krallık Sayıştay'ının 2009 raporuna göre yerel yönetimlerin imzaladığ 1 KÖO sözleşmelerinin $\% 95$ 'i (sermaye değerine göre) bilanço dışıdır (NAO, 2009: 36).

Eurostat, borçların bilanço dışında tutulmasını güçleştirmek için muhasebe standartlarında değişikliklere gitmiştir. Nisan 2009 tarihinde Birleşik Krallık'ta International Financial Reporting Standards yöntemine geçilmiş ve KÖO projelerinin çoğunluğu kurumların bilançolarına dahil edilmiştir. Yöntem değişmiş olsa bile Sayıştay'ın tespitine göre, kamu kesimi net borçlanmasının hesaplanmasında KÖO yükümlülüklerinin hâlâ bütçe dışı kaldığı görülmektedir (NAO, 2011: 20). Burada önemli bir diğer nokta zaten 1992 yılından beri son derece büyük yatırımların bilanço dışında gerçekleştirilmiş olmasıdır.

Nisan 2009'dan sonra yeni düzenlemelerle yerel yönetimlerin de projelerini bilançolaştırmalarının sağlanacağ umulmaktadır. Bilanço dışılı̆̆ın yerel yönetimler düzeyinde yaygınlaşmasının en önemli nedeni yerel düzeyde

\footnotetext{
${ }^{14} 1990$ 'larda Maastricht kriteri buna bir örnektir.

${ }^{15}$ Birleşik Krallık Sayıştayı'nın raporuna göre yapılan mülakatlarda pek çok proje yöneticisine göre modelin tercih edilmesindeki en temel neden, borcun bilanço dışında kalmasını sağlamasıdır (NAO 2009: 8).
} 
imzalanan KÖO sözleşmelerinin pek çoğunun, hükümet tarafından örtük olarak garanti altına alınmasıdır. Sayıştay bunu KÖO kredileri (PFI credits) olarak adlandırmaktadır. Yerel yönetimler bu kredileri, merkezi yönetimden elde edilecek kaynak transferi olarak görmektedir. Bilançolaştırılmış bir projenin merkezi yönetimden bu tür bir destek alması olanaksızdır. Örtük olarak vaat edilen bu KÖO kredileri bütçe sürecinin dışında kalmaktadır. Bu durum yerel yönetimlerin de bilanço dışına kaymalarını teşvik etmektedir (NAO, 2009: 38, 39).

$\mathrm{Bu}$ tür yatırımların bilanço dışında kalmasının kamu maliyesi açısından sadece basit bir saydamlık sorunu yaratmadığı son derece büyük bir mali risk anlamına da geldiği deneyimlerle de ortaya çıkmıştır. Londra metro inşaatının bir kısmının KÖO modeliyle gerçekleştirilmesi sırasında ${ }^{16}$ Metronet isimli firmanın iflası ile 400 milyon sterlin birdenbire kamu borcuna dönüşmüştür. Şarta bağlı borcun herhangi bir istatistikte yer almaması nedeniyle kamu maliyesinin gerçek bilançosu ancak iflas anında ortaya çıkabilmiştir (Price, 2009).

Birleşik Krallık Sayıştayı'nın raporuna göre, ilgili projelerin bilanço dışında kalmasını sağlamak için kamunun ilgili projelere ilişkin şu düzenlemeleri tercih ettiği görülmektedir: Ortak girişimde kamunun payını \%50'nin üzerine çıkarmamak; talep riskini düşük göstermek, ilgili varlıkların kullanımının beklenenden düşük düzeyde gerçekleşeceğini düşünmek; nihai etapta devralınacak olan varlıkları riskiyle birlikte yükleniciye bırakmak; nihai etapta devralınacak olan varlığın değerini düşürmek için proje süresini arttırmak; kredilerin finansmandaki oranını \%90'ın altında tutmak; sözleşmeye projenin kısmi iptaline ilişkin hüküm koymamak; bina bakım giderlerini yüklenici firmaya bırakmak; kamu kira ödemesinin, yüklenici firmanın borç geri ödemesiyle bağlantılı olmamasını sağlamak (NAO 2009: 40, 41).

Sadece kamunun değil, özel firmanın da, projeyi bilanço dışında tutmaya çalıştığını vurgulamalıyız. Önceki bölümlerde görüldüğü üzere Birleşik Krallık'ta KÖO modelinde yüklenici firmaların, başvurmaları durumunda karma tüccar statüsüne alınmakta ve böylelikle proje kapsamındaki tüm maliyetleri vergi matrahından düşebilmelerine olanak tanınmaktadır. $\mathrm{Bu}$ durum, Sayıştay'ın belirttiği gibi varlıkların ne kamuda ne de özel kesimde

\footnotetext{
16Parlamento'daki karma komisyonlardan Ulaşım Karma Komisyonu (Transport Select Committee) ilgili KÖO sözleşmelerinin kusurlu olduğunu ve modelin kamu kaynaklarının israfına neden olduğunu tespit etmiştir (TFL 2010).
} 
bilanço içine alındığı durumu (off-off accounting) teşvik etmektedir (NAO 2009: 41). ${ }^{17}$

Bilanço dışılığın sadece kamu maliyesi krizine ilişkin değil, uluslararası ölçekte makro ekonomik krize ilişkin etkileri de göz ardı edilmemelidir. Enron firmasının iflasını hazırlayan mekanizmalar ve 2008 krizini hazırlayan koşullar ile KÖO modelinin bilanço dışılık sorunu ve modelde muhasebe şirketlerinin üstlendiği roller tehlikeli bir şekilde benzerlikler arz etmektedir. Gosling'in (2003: 4) vurguladığı gibi ABD'de 2000'lerin hemen başında yaşanan WorldCom, Enron ve Global Crossing şirketlerinin iflaslarında muhasebe firmalarının önemli bir payı vardır. Yatırım bankaları ve muhasebe firmalarının bilanço dışı mekanizmalar kullanarak büyük şirketleri finanse etmesi, gelişmiş ülkelerde yaşanan hızlı büyümenin gerisindeki mekanizma olmakla birlikte aynı olgu gerek dot.com gerekse de 2008 Eylül krizlerini hazırlamış ve derinleştirmiştir. KÖO modelinde kamu kesiminin destek aldığ $\breve{l}_{1}$ ve ortaklık kurduğu özel sektör kurumlarının, ki ilerleyen başlıkta ele alınacaktır, muhasebe şirketleri ve yatırım bankaları olması bu açıdan eleştirel bir değerlendirmeyi gerektirmektedir.

$* *$

Sadece ulusal hesaplar sistemindeki tanımlar itibariyle modelin bilanço dışında kalma sorununun olmadığı aynı zamanda, modele ilişkin yeterince bilginin toplanamaması, merkezi düzeyde anlamlı bir istatistiğin oluşturulamaması ve kamuoyu ile paylaşılamaması açısından da modelin sorunlar yarattığı gözlemlenmektedir. İç ve diş denetimin son derece güçlü olduğu Birleşik Krallık'ta bile modelin uygulama ve sonuçlarına ilişkin yeterince bilgi toplanamaması ve bu duruma ilişsin eleştirilerin başta Sayıştay tarafından gündeme getirilmesi anlamlıdır.

Modelin karmaşık ve uzun süreli bir sözleşmeye dayanan yapısı bilgi eksikliğinin doğuracağı sorunları arttırmaktadır. Sözleşmeyi imzalayan

\footnotetext{
${ }^{17}$ İskoçya'da yapılan hapishane, ne kamunun ne de hizmet sağlayıcı firmanın bilançosunda görülmektedir. Hapishane muhasebe perspektifiyle baktığımızda kimseye ait değilmiş ya da herhangi bir yükümlülükle ilişkilendirilmemiş görülmektedir (Gosling, 2003: 4). Türkiye'de sağlık alanında uygulanan KÖO modelinde kayıt sorununun bir başka biçimi ortaya çıkmaktadır. Onur Karahanoğulları'nın işaret ettiği üzere yasalarda, Hazine'ya ait taşınmazların özel girişimlere proje dahilinde bedelsiz devirleri ardından, taşınmaz üzerine yapılacak tesisin mülkiyetinin kime ait olacağına ilişkin hiçbir belirleme bulunmamaktadır (O. Karahanoğulları 2011: 187). Bu durum pek çok hukuksal sorun ve risk de doğurmaktadır ki bunların maliyet etkilerinin de olması beklenilebilir.
} 
yüklenici firmanın işlerin bir bölümünü taşeron firmalara aktarması durumunda kamunun bilgi eksikliği sorunu daha da derinleşmektedir. Sözleşmeler tamamlandıktan sonra da, özel firmanın yaptığı faaliyetlere ilişkin bir saydamlığın söz konusu olmaması kamu kaynaklarının yerinde bir şekilde kullanılıp kullanılmadığının belirlenmesinde sorunlar yaratmaktadır. İngiltere'de Savunma Bakanlığı'nın Tanker Uçak üretimi için imzaladığı projenin uygulama aşamasındaki firmanın maliyetlerine bakanlığın ancak kısmen ulaşabilmesi ve bu firmanın taşeron firmalara verdiği işlere ilişkin bilgilere ise hiçbir şekilde ulaşamaması, maliyet değerlendirilmesini ve alternatiflerle karşılaştırılma yapılmasını olanaksız kılmıştır (NAO 2011: 17). Özel firmanın ticari kazancının açıklanmasına ilişkin sözleşmelerde zorlayıcı bir maddenin olmaması yatırımcılar açısından da saydam olmayan bir durum yaratmaktadır; hisse sahibi yatırımcılar bile projenin getirisine ilişkin yeterli verilere ulaşamamaktadır (NAO, 2011: 25).

Performansın, verimlilik ve etkinlik gelişiminin takip edilmesini olanaksız kılan bu yapıda özel firmanın hastanelere verdiği aynı yemek için zaman zaman 3 sterlin, zaman zaman da 12 sterlin fiyat biçmesi gibi rasyonel olmayan olgular ile karşılaşılabilmektedir. Birleşik Krallık'ta, Sağlık Bakanlığı'nın Kamu Hesapları Komisyonu'nda, KÖO modeliyle yapılan hastanelerde çıkarılan yemeklerin fiyatlarının niçin 3 ile 12 sterlin gibi rakamlara inip çıktığı konusunu açıklayamadığı not edilmektedir (NAO, 2011: 22). Benzer şekilde çamaşırhane hizmeti fiyatının da 20 ile 96 peni arasında rasyonel olmayan şekilde değişmesi açıklanamamaktadır. Ulusal Sağlık İdaresi'nin 2008 yılından sonra hizmet maliyetlerini derlemeyi bırakmış olması da bu konuda daha ayrıntılı bir inceleme yapılmasını olanaksız kılmaktadır (Pollock vd., 2011: 418).

\section{Danışman Desteğine Bağımlılık, Esneklik Sorunu, Çalışma Koşullarını Yeniden Biçimlendirme}

Muhasebe firmaları, yatırım bankaları, tesis yönetim firmaları, mülk geliştirme firmaları (property developer) inşaat firmaları bu yatırımlarda ticari çıkarı olan öznelerdir. İlginç olan nokta bu aktörlerin her birinin, KÖO modeline ilişkin karar aşamalarında açık ya da gizli söz sahibi olmalarıdır.

Muhasebe ve danışmanlık firmaları, bu yatırımların temel kurallarını belirleyen, takip eden, kendi adına ihalelere giren, ihaleye giren şirketlere danışmanlık hizmeti veren, kamu otoritesine hangi projenin seçilmesi gerektiği konusunda danışmanlık yapan ve KÖO modeli için kamuoyu oluşturan öznelerdir. Birleşik Krallık'ta Hazine'nin beş büyük muhasebe ve danışmanlık 
firmasını, KÖO modelinin şekillendirilmesi için 2002 yılına kadar toplam 442 projede görevlendirdiği görülmektedir. Bunlar arasında İngiltere'nin büyük muhasebe şirketleri PricewaterhouseCoopers, KPMG, Ernst\&Young, Deloitte\&Touche, Andersen ve daha sonra Enron yolsuzluğunda pay sahibi olacak bir şirketin de olduğu vurgulanmalıdır. Muhasebe ve danışmanlık firmalarının bir taraftan bu projelerin yaygınlaşması için çaba göstermeleri diğer taraftan ihale sürecinde önemli bir aktör olarak varlıkları, hem ihaleye giren firmalara hem de devlete ihale sürecinde danışmanlık yapmaları, modelin ticari ayağına ilişkin kuşkulu bir tablo yaratmaktadır.

Kamu otoritesinin KÖO ihalelerinde gerçekten bağımsız bir danışmanlık hizmeti almaları neredeyse olanaksız görünmektedir (Gosling, 2003: 9). KÖO projelerinin kamuya \%17 tasarruf sağlayacağını anlatan raporu bu sistemden ticari çıkarı olan bir muhasebe şirketinin yayımlaması ve üstelik bu şirketin daha sonra Enron skandalı ile bağlantılı olarak itibarsızlaşan bir şirket olması çarpıcıdır (Gosling, 2003: 5).

Yatırım bankaları, KÖO yatırımlarına kredi veren büyük ve sınırlı sayıda finans şirketleridir. 2002 tarihi itibariyle RBS 10,8 milyar sterlin değerinde 64 proje, HBOS 10,7 milyar sterlin değerinde 45 proje, Abbey National 9 milyar sterlin değerinde ve Barclays 2,5 milyar sterlin değerinde 44 proje finansmanı sağlamış ve KÖO modelinin büyük yatırımcıları olmuşlardır (Gosling, 2003: 11). Bu firmalar projelerin finansmanını gerçekleştirirken hem bazı projeler için finansal danışmanlık hizmeti verebilmekte, hem de yatırımı üstlenen ilgili firmada hisse sahibi olabilmektedirler. ${ }^{18}$

${ }^{18}$ Birleşik Krallık'ta kamu yatırımlarının KÖO modeliyle yapılmasını yaygınlaştırmak üzere PPPForum, Partnership UK ve Local Partnerships isimli özel kuruluşlar faaliyet göstermektedir. RBS, UBS Barclays, Dexia, Lloyds gibi büyük bankalar, Siemens, Balfour Beatty Capital, PricewaterhouseCoopers gibi şirketler PPPForum'un ortakları arasındadır (PPPForum, 2011). Serco, Group 4 ve Jarvis gibi tesis yönetim şirketlerinin de PPPForum'a ortaklı̆ğ vardır. PPP Forum, Birleşik Krallık Hazinesi'nde projelerinin takibinde, modele ilişkin düzenlemelerin şekillendirilmesinde, politika grupları kurarak son derece aktif bir rol oynamaktadır. Politika grupları arasında özellikle muhasebe ve vergi konularında Hazine ile aktif toplantılar yapabilmekte ve ticari pozisyonunu geliştirebilmektedir. Partnership UK ise \%49'u kamuya \%51'i özel kesime ait bir kurumdur. Hükümetin KÖO yatırımlarını geliştirmesine yardımcı olan, KÖO projelerinin seçiminde danışmanlık hizmeti vermekte ve KÖO modelinin yaygınlaşmasını destekleme amacını gütmektedir. Local Partnerships, yerel düzeyde kamu kurumlarına KÖO modellerinde ticari danışmanlık desteği sunan \%50 Hazine'nin \%50 de Local Government Association ortaklığı ile kurulan bir şirkettir. Danışmanlık hizmeti 
Kamu personelinin, ticari becerilerinin ve proje yürütme bilgilerinin genellikle zayıf olması, özel kesim ile bu büyüklükte bir ortaklık ilişkisine girilirken kamu kesiminin ticari pozisyonunu zayıf bırakmaktadır. Bu boşluğu kamu otoritesi, yine özel kesimden geçici danışmanlık hizmeti satın alarak doldurmaya çalışmaktadır. $\mathrm{Bu}$ ise projenin maliyetlerinin artmasına neden olmaktadır. Daha da önemlisi ise danışmanlık şirketinin çekilmesi durumunda projeye ilişkin tüm ticari bilgilerin kaybedileceği bir bağımlılığın yaratılmış olmasidir (NAO, 2009: 59).

Kamu kurumlarının teknik ve ticari değerlendirmeler yapabilecek imkanlardan mahrum olması ya da mahrum bırakılması, kamunun danışman şirketlere aşırı bağımlılığı bu tür modellerin yarattığı önemli problemler arasindadir. Londra'da M25 otoyolu projesinde Otoyollar Kurumunun (Highways Agency), yoğun bir şekilde dışarıdan danışmanlık hizmeti alması, uzman personel sayısını azaltması, sonuçta danışman firmaların projeyi kontrolüne alması ve projeye ilişkin çok fazla bilgiyi ele geçirme gibi bir riskin oluşması bu sorunlara örnek olarak gösterilmektedir (NAO, 2011: 23).

$*$

Modelde finansman gerekliliğinin özel kesim tarafından karşılanıyor olması ve doğal olarak yatırımların finansmanı için ağırlıklı bir şekilde bankalardan borçlanılması nedeniyle, geri ödeme süresinin son derece uzun olduğu bir ilişki yaratılmaktadır. Kamu ile özel kesim arasında bağıtlanan hizmet sözleşmelerinin uzunluğunun gerekçelerinden biri de bu kredi ilişkisinin uzunluğudur. Kamu otoritesinin, kamu hizmeti üretimi için, bu kadar uzun süreli bir ilişkiye giriyor olması ise hizmet üretiminde esneklikleri ortadan kaldırmaktadır (NAO, 2011: 13).

Kriz gibi olağan dışı koşullara karşı, piyasa ilişkilerinden farklı olarak esnek politika araçlarına sahip olması ve bazı hizmet alanlarında hizmet üretiminin sürekliliğini sağlama zorunluluğu kamu maliyesinin en önemli tanımlayıcılarıdır. KÖO modelinin yarattığı katılıkların, kamu otoritesinin elindeki araçları yok etme ya da maliyetlerini arttırarak işlevsiz kılma riskini yarattığını söyleyebiliriz.

İhale şartnamelerinde işin tamamlanamaması durumunda sözleşmenin feshedileceğine dair maddeler eklense bile, ilgili ihaleyle başlanılan ekonomik ilişkinin tekelci bir yapı yaratmış olması nedeniyle bu maddenin uygulanması pratikte neredeyse olanaksız hale gelmektedir. Böyle bir durumun doğuracağ 1 iktisadi dengesizliğin, sözleşme yapılırken kullanılan fayda-maliyet analizleri

verilen yerel idareler arasında, polis, itfaiye, sağlık ve sosyal dayanışma kurumları yer almaktadır. (http://www.localpartnerships.org.uk, 2011). 
ile analiz edilmesi beklenilemez. Anlaşma imzalandıktan sonra kamu kesimi için projeyi iptal etme maliyeti çok yüksektir ve sözleşme son derece uzun bir dönemi bağlamaktadır. Bunun üzerine bir de projelerin parasal büyüklüğü eklendiğinde, ticari riskin yükselmesi olgusu ile karşılaşılmaktadır ${ }^{19}$ (NAO, 2011: 13).

Uluslararası kredi derecelendirme kuruluşu olan Standard\&Poor's, kamu otoritelerini KÖO yükümlülüklerin yarattığı katılıklar nedeniyle uyarmakta ve kamunun kredi derecesini düşürebilmektedir. Kurum, KÖO modelini bütçe diş1 görmemekte, kamu borcu olarak (tax-supported debt) değerlendirmektedir. Buna göre kurum, Madrid Otonom Bölgesinin finansal görünümünü, yani kredi derecesini, kamu harcamalarında KÖO modelinin yarattığ katılıklar ve finansal yükümlülükler nedeniyle negatife çevirmiştir. (Hall, 2009: 4).

**

Modelde çekirdek hizmet alanının kamu otoritesinin sorumluluğunda kalması modelin ayırt edici yapısal bir özelliğidir. Böylece talep riskini kamu otoritesi üstlenmektedir ve klasik anlamda bir yap-işlet-devret modelinden ya da hizmetin piyasa mekanizması dahilinde doğrudan özel kesim tarafından üretiminden farklı olarak özel girişimin kâr güvencesine kavuştuğu bir model yaratılmaktadır (Karasu, 2011: 228, 244) (O. Karahanoğulları, 2011: 182).

Özellikle sağlık alanındaki yatırımlar için KÖO modelinin yarattığ sakıncalardan biri de, bu derece büyük ölçekli ve entegre tesislerin kurulmasının yarattığı tekelleşmedir. Sağlık hizmeti alan yurttaşların, KÖO sözleşmesinin yapısal bir dayatması olarak diğer ihtiyaçlarını projenin tasarımsal gereği olarak, özel amaçlı şirketin işlettiği diğer tesislerden karşılaması bir zorunluluğa dönüşmektedir. Modelin kendisi, kamu hizmeti alan vatandaşları özel şirketin müşterisine dönüştürdüğü bir tablo yaratmaktadır (Karasu, 2011: 244). KÖO modelinin bir sonucu olarak, piyasada tekelci bir alan ortaya çıkmaktadır. Kamu otoritesinin tercihleri sonucu, sadece özel girişimin talep riski garanti altına alınmamakta, piyasanın rekabetçi koşulları tasfiye edilmektedir.

Judith Richter, KÖO modeli son derece büyük riskler taşırken, modelin olumlu çağrışımları barındıran "ortaklık" kavramıyla adlandırılmasının ilgili risklere gerektiği gibi işaret edilmesine engel olduğunu ve modelin bunun

${ }^{19}$ David Price, özellikle yabancı yatırımcılarla yapılan KÖO sözleşmelerinde uluslararası anlaşmalardan kaynaklanan katılıkların da işin içine girdiğini; bu tür projeler için özellikle kriz konjonktürünce yasa değişikliğine gitmeyi engelleyen uluslararası anlaşma hükümleri nedeniyle hükümetlerin ellerinin bağlandığını vurgulanmaktadır. Price, Latin Amerika'daki su-elektrik projelerini buna bir örnek olarak göstermektedir (Price, 2009). 
yerine daha az değer yüklü bir kavram ile ifade edilmesi gerektiğini vurgulamaktadır (Richter, 2004: 47).

$* * *$

KÖO modelinin, performans yönetim mekanizmaları ile hizmet sunumunun kalitesini arttırmayı teşvik edici mekanizmalara sahip olduğu düşünülmektedir. Oysa bu mekanizmalar kamunun istihdam modelini dönüştürücü etkiler yaratabilir. Birleșik Krallık Sayıştay’1 performansa yönelik gündeme getirilen yeniliklerin, işçilerin aleyhinde mekanizmalara yoğunlaşması riski nedeniyle tartışmalı olduğunu, kamu yararı ilkesinin iş̧ilerin haklarını feda ederek gerçekleştirilmemesi gerektiğini, yasal düzenlemelerin, kamudan özele geçen işçilerin haklarını korumayı hedeflemesi gerektiğini vurgulamaktadır (NAO, 2009: 30).

UNISON'un da vurguladığı gibi kamu hizmetlerinin, işin niteliği gereği emek yoğun olması, KÖO ihalesini alan şirketlerin daha çok kâr elde edebilmek için öncelikle çalışanların haklarına müdahale etmek isteyecekleri riskli bir durum yaratmaktadır (UNISON, 2005: 4). Özel kesim genellikle, projelerin toplam maliyetini düşürmek için, işçi ücretlerinden ve sosyal güvenlik ödeneklerinden tasarruf etmeye çalışmaktadır (Gosling, 2003: 3). Daha önce kamu personeli olarak çalışanların, özel şirket istihdamına geçmesi, sadece basit bir isim değişikliği olarak kalmamakta, iş ilişkilerinin ve işin tanımının da değişmesi anlamına gelmektedir.

Birleşik Krallık Sayıştay’1 2004 yılında 43 KÖO modelini incelemiş ve kalifiye olan yönetici düzeyindeki çalışanlar için kamu ile özel kesim arasında çalışma koşulları ve ücret bakımından fark olmadığını ancak en düşük nitelikteki çalışanlar için koşulların özel kesimde daha kötü olduğunu, bu farkın bir süre sonra daraldığını ortaya koymuştur (NAO, 2009: 30). Nitelikli personelin ve yönetici kadroların toplam istihdama oranı düşünüldüğünde kamu emekçilerin geneli için KÖO modelinin çalışma koşulları ve ücretler bakımından yarattığı riskin önemi daha kolay anlaşılacaktır.

Kamu hizmetinin giderek daha fazla bir şekilde KÖO modelleriyle yürütülmesi, iki katmanlı emek gücü (two tier workforce) denilen olguyu gündeme getirmektedir. Bir tarafta iş güvencesi, çalışma koşulları ve ücretleri göreli olarak daha iyi olan ancak kamu alanının daraltılması nedeniyle sayıları azalan kamu personeli ve diğer tarafta da daha önce kamu adına çalışan ancak şimdi KÖO ihalesini kazanan şirkete transfer olan, ücretleri daha düşük, sosyal güvencesi ve çalışma koşulları son derece sorunlu olan emekçiler, aynı iş için 
iki farklı istihdam modeli oluşturmaktadır20 (UNISON, 2005: 4). Bu tür iki katmanlı bir emek piyasasının orta vadede ulusal ekonominin verimliliği ve büyüme potansiyeli üzerinde de tahribat yaratması olasıdır. ${ }^{21}$

İstihdam modelinin bu şekilde dönüşmesinin yarattığı olumsuz sonuçlardan biri de çalışma motivasyonuna ilişkindir. Moral ve etkinlik kaybı KÖO modeliyle faaliyet gösteren hastanelerde tespit edilen sorunlar olarak ortaya çıkmakta, aynı iş için farklı istihdam modellerinin uygulanması çalışanlar arasında husumete neden olmaktadır. Yemek hizmetlerinde işçi çıkarıp yeniden işçi alma oranının yılda \%10-15'ten KÖO modeli sonrasında \%100'in üzerine yükseldiği tespit edilmiştir (Hall, 2008: 20).

Modelin sadece istihdam rejiminin yapısını ve istikrarını bozma riski değil hizmetin niteliğini bozma riski de vardır. David Price'ın vurguladığı gibi (2009), KÖO sözleşmelerini kazanan firma da hizmetlerin bir kısmını taşeronlara devredebilmekte, hizmet sağlayıcıları el değiştirebilmekte ve İngiltere'de olduğu gibi, ilgili kamu hizmetinin, kimin tarafından sağlandığının net olarak bilinmediği bir tablo ortaya çıabilmektedir.

Hizmet üretiminin amacı, niteliği değişebilmektedir. Kamu otoritesinin, kamu özel ortaklığı daire başkanlığına veya ihale birimine indirgenmesi, sağlık kamu hizmetinin kamu hizmeti alanında imtiyazlar ve ihaleler alan özel girişimcilerin idarece denetlenen işletmelerine dönüşmesi riski söz konusudur (O. Karahanoğulları, 2011: 204). KÖO modelinde, özellikle Türkiye'de sağl1k alanındaki uygulamalara ilişkin olarak, projelerde tıbbi olmayan hizmet ve ticari alanlarda faaliyet gösteren özel amaçlı şirketin hastanenin yönetiminde paydaş olarak etkili bir şekilde söz sahibi olma olasılığı söz konusudur (Karasu, 2011: 233).

Modelde performansı arttıran şey modelin tasarımı ya da istihdam modelindeki kesintiler değil, uygulama sırasında hizmetlerden yapılan kesintiler de olabilmektedir. İngiltere'de Ulusal Sağlık İdaresi'nde ortaya çıkan deneyim, KÖO modelinin maliyetinin hizmet tarafından yüklenildiği

${ }^{20}$ David Hall, Birleşik Krallık'ta KÖO modelinin ardından kamu hastanelerinin çekirdek hizmet dışı alanlarında dört farklı istihdam modelinin ortaya çıktığını belirtmektedir. $\mathrm{Bu}$, benzer işi yapan emekçiler için eşit olmayan koşulların yaratılması anlamına gelmektedir. Bu durum bazı istihdam türlerinin örneğin hafta sonu için fazla mesai ücreti alabildiği bazılarının ise alamadığı eşitsiz koşullar ortaya çıkmaktadır (Hall, 2008: 20).

${ }^{21}$ Kriz öncesi dönemde ikili bir emek piyasası sayesinde güçlü büyüme elde eden İspanya'da kriz sonrası süreçte milyonlarca genç işsizin tekrar iş aramayabilmek ve emeklerinin niteliğini arttırabilmek için istek ve olanaktan yoksun kalması modelin konjonktürel yapısını ve tahrip edici boyutunu ortaya koymaktadır. 
yönündedir. Bu durum daha küçük kapasiteli hastanelerin inşa edilmesinde görülebilmektedir. Kamu özel ortaklığıyla inşa edilen yeni hastanelerde yatak kapasitesinin $\% 30$ oranında azaltıldığ 1 ve sağllk hizmetlerinin diğer alanlarında da kesintiye gidildiği görülmektedir (Price, 2009).

\section{Sonuç}

Kamu otoritesinin KÖO modeline başvurmadaki temel amacının, ilgili yatırımların mümkün olduğunca kısa bir süre içinde ve belirli bir bilanço dâhilinde gerçekleştirilmesini sağlamak olduğu görülmektedir. Kamu ile özel kesimin yapısal üstünlüklerinden yararlanmak ve projenin risklerini kamu ile özel kesim arasında paylaştırarak toplamda projenin verimliliğini artırmak modelden temel beklentilerdir. Genel tasarımı ve uygulamaları değerlendirildiğinde modelin kendisinden beklenilen sonuçlara ulaşma konusunda, geleneksel kamu hizmet üretim modeline göre mutlak bir üstünlügünün olmadığ 1 ve hatta pek çok alanda yeni riskler yaratması itibariyle başarısız kaldığı görülmektedir.

Son derece uzun süreli ve büyük çaplı bir sözleşmeye dayanan bu modelin tekil projelerin fayda/maliyet analizleri çerçevesinde değerlendirilmesi yerine, maliye perspektifiyle kamu kaynaklarının değerinin korunup korunmadığı sorunsalı etrafında değerlendirilmesi gerekmektedir. Modelin ilk kapsamlı uygulamalarının gerçekleştirilmiş ve halihazırda da neticelerinin alınmış olması ve modelin sonuçlarının bağımsız denetim kuruluşları tarafından ayrıntılı bir şekilde incelenmiş olması Birleşik Krallık örneğini, bu tür bir analiz için değerli bir referansa dönüştürmektedir.

Kamu kesiminin cebinden para çıkmaksızın büyük yatırımların gerçekleştirilebileceği tezinin ne derece geçersiz olduğu KÖO modelinin maliyetleri incelenirken ortaya konmuştur. Özellikle kriz sonrası konjonktürde modelin maliyet sorununun daha da derin bir hal aldığı görülmektedir. Model çerçevesinde ilgili projelerin bütçe dışında kalması, kamu kesiminin net borçlanma gereksinimi tanımını etkilememesi, kamu mali disiplini ve saydamlık bakımından önemli sorunlar yaratmaktadır. Saydamlık sorunu sadece muhasebe problemi olarak ortaya çımamakta, kamuoyunun ve kamu otoritesinin ilgili yatırımlar hakkında güvenilir veriler elde edememesi anlamında da problemler yaratmaktadır. Büyük çaplı ve uzun vadeli ticari ilişsilerin bu sözleşmelerle kurulması, kamu otoritesinin planlama becerisini kısıtlamakta, türlü katılıklar yaratmaktadır. Bir diğer sorun ise bu ilişkinin kurulması, uygulanması ve denetlenmesi aşamalarında kamu otoritesinin kurumsal yapı ve personel kapasitesi bakımından zayıf kalması ve özel kesimden alınan danışmanlık desteğine olan yüksek bağımlıktır. KÖO modeli 
ile istihdam modelinin değişmesi ve ikili bir işgücünün yaratılması da önemli bir risk olarak gündemdedir.

Kriz koşullarının özellikle gelişmiş ülkelerde durgunluk yaratması ve büyük çaplı yatırım projelerinin finansmanının giderek daha da zorlaşması KÖO modeli için önemli bir handikap yaratmaktadır. Böyle bir konjonktürde, finansman kuruluşlarının, projelere kredi vermek için kamu garantileri talep etmeye başlamaları önemli bir olgu olarak ortaya çıkmaktadır. Normalde risklerin finansman sağlanamayacak düzeyde artması kamu kesiminin bu modeli tercih etmemesini gerektirecekken, özellikle uluslararası finansman kuruluşlarının talepleriyle kamu, projeler için garanti vermek durumunda kalmaktadır.

Birleşik Krallık'ın KÖO modeliyle ilgili deneyimi gelişmekte olan ülkeler için de son derece önemli sonuçlar üretmiştir. İlginç bir husus, Birleşik Krallık gibi güçlü bir ekonominin iktisadi kriz sonrasında KÖO projelerini finanse eden bankaları kurtarmak zorunda kalmasıdır. David Hall, 2008 krizi sonrasında Birleşik Krallık'ta kurtarılan bankaların kamuya maliyetinin o tarihe kadar imzalanan KÖO projelerinin toplam değerinden daha büyük olduğunu ve KÖO modeline ilişkin geliştirilen "başka bir alternatif yok" mitinin gerçek dışılığını vurgulamaktadır (Hall 2008: 14).

$\mathrm{Bu}$ noktada ilginç bir örneğe vurgu yapılabilir. Birleşik Krallık'ta Hazine, 2009 Mart ayında Altyap1 Finansman Birimi (The Infrastructure Finance Unit- TIFU) kurmuş ve piyasa kuralları ve oranları çerçevesinde yani bir özel finans şirketi gibi KÖO projelerinin finansmanına girmesine olanak sağlamıştır. 2010'da Comprehensive Spending Review ile bu olanak ortadan kaldırılsa bile, (EPEC 2011: 18) bu olgu göstermektedir ki, kamu kesimi gerektiğinde geleneksel yatırım modeline yakınlaşan alternatifler yaratabilmektedir.

2008 sonrası konjonktürde, gelişmiş merkez ülkelerden farklı olarak kamu maliyesinin dengede olduğu ya da fazla verdiği gelişmekte olan ülkelerin, kamu yatırımlarını ve hizmetlerini doğrudan kendi kaynaklarıyla kendisinin üstlenmesi, bir olasılık olarak her zaman değerlendirmeye tabii tutulmalıdır. Ülkemizde İstanbul Boğazı'na yapılması planlanan üçüncü köprünün ihale sürecinde yaşanan kriz böyle bir değerlendirmenin gereksinimini zorunlu olarak doğurmuştur. Ancak bu tür politika alternatifleri sadece ihale krizinin yaşandığı alanlar için değil çok daha büyük yatırımların yapıldığı özellikle sağlık alanı için de gündeme gelmelidir. Kamu kesimi, piyasa ekonomisinden farklı olarak siyasi karar alabilme gücü sayesinde her zaman alternatifler yaratabilme olanağına sahipken tekil bir modele mahkum bırakılma riski ile karşı karşıya kalmamalıdır. 


\section{Kaynakça}

Black, Sophie (2003), "Composite Trader Status", The PPP Journal, http://www. publicservice.co.uk/article.asp?publication=The\%20PPP\%20Journal\&id=16 \&content_name=Legal\&article=414 (15.09.2011).

Committee of Public Accounts (2011), PFI in Housing and Hospitals, Fourteenth Report of Session 2010-2011, HC 631, Ocak 2011, http://www.parliament.uk/pagefiles/53537/CRC\%20final.pdf (01.09.2011).

EPEC, European PPP Expertise Centre (2011), State Guarantees in PPPs: A Guide to Better Evaluation, Design, Implementation and Management, http://www.eib.org/epec/resources/epec-state-guarantees-in-ppps-public.pdf (10.06.2011).

Gosling, Paul (2003), "How the Big Four Accountancy Firms Have PFI Under Their Thumbs", UNISON Report, www.unison.org.uk/acrobat/b681.pdf (15.10.2011).

Hall, David (2008), "Critique of PPPs", Public Services Inetrnational Research Unit (PSIRU), http://www.psiru.org (15.10.2011).

Hall, David (2009), "A Crisis for Public-Private Partnerships (PPPs)?”, Public Services Inetrnational Research Unit (PSIRU), http://www.psiru.org/reports/2009-01-crisis-2.doc (15.10.2011).

Hoicka, David (2007) "Public Private Partnerships and Affordable Housing", http://www.slideshare.net/DavidHoicka/public-private-partnerships-ppp-and-affordablehousing-by-david-hoicka (15.10.2011).

HM Treasury (2011), PFI Data Summary, http://www.hmtreasury.gov.uk/d/pfi_data_summary_march2011.pdf, (01.10.2011).

http://www.jaspers-europa-info.org/index.php/about-us.html, (10.01.2012).

http://www.kamuozel.gov.tr/?Islem=YaziKategorileri\&BolumID=7, (10.01.2012).

http://www.localpartnerships.org.uk/ (15.10.2011).

http://www.swap-rates.com (15.12.2011).

Karahanoğulları, Onur (2011), "Kamu Hizmetleri Piyasa Illişkisinde Dördüncü Tip: Eksik İmtiyaz (Kamu Özel Ortaklığı)”, Ankara Üniversitesi SBF Dergisi, Cilt 66, No. 3, s. 177-215.

Karasu, Koray (2011), "Sağlık Hizmetlerinin Örgütlenmesinde Kamu-Özel Ortaklığı", Ankara Üniversitesi SBF Dergisi, Cilt 66, No. 3, s. 217-262.

McKee, M., Nigel Edwards ve Rifat Atun (2006), "Public-Private Partnerships for Hospitals", Bulletin of the World Health Organization, Cilt 84 (11), s.890-896.

National Audit Office (2009), Private Finance Projects, A Paper for the Lords Economic Affairs Committee. 
National Audit Office (2011), "Lessons from PFI and other Projects", Report by the Comptroller and Audit General, 28 Nisan 2011.

Pollock, A., David Price ve Moritz Liebe (2011), "Private Finance Initiatives During NHS Austerity", BMJ, Cilt 342, s. 417-419.

PPPForum (2011), Annual Review, http://pppforum.com/sites/default/files/blocks/annualrev/Annual\%20Review\%202011_low.pdf (15.09.2011).

Price, David (2009), "Kamu-Özel Ortaklığının Faydası Net Değil”, http://www.euractiv.com.tr/6/interview/kamu-zel-sektre-ortakInn-faydas-net-deil-007038 (15.09.2011).

Richter, Judith (2004), "Public-Private Partnerships for Health: A Trend with no Alternatives?", Development, Cilt 47, Sayı: 2, s.43-48.

Transport For London (2010), Transport Select Committee Confirms Tube PPP is 'Flawed' and has 'Failed to Prove' Value for Money, http://www.tfl.gov.uk/corporate/media/newscentre/archive/15116.aspx (15.06.2011).

UNISON (2005), Overview of Public Private Partnerships in the UK, Unison Briefing, June 2005, www.unison.org.uk/acrobat/B1924.pdf (15.10.2011). 